\title{
PEREMPUAN DAN HUKUM DALAM MASYARAKAT HUKUM ADAT LAMPUNG SEBATIN
}

\author{
Zuhraini \\ Dosen Fakultas Syari'ah UIN Raden Intan Lampung \\ email : zuhraini@radenintan.ic.id \\ Diterima: 06 Mei 2017. Disetujui: 08 September 2017 \\ Dipublikasikan: November 2017
}

\begin{abstract}
The interpretation of the Qur'an is often disputed. The terms of custom, culture and ideology is not one thing that descends from the sky. It is shaped by humans and socialized from one generation to other. Biological determinism has also reinforced the view. In such situations, the differences, discrimination, and injustice resulting from mistakes in understanding and interpreting the universal doctrine, create injustices against women, including the women's rights and position in Lampung Sebatin customary law community. This article discusses the rights and position of women in Lampung Sebatin customary law community and the form of injustice for women in the society. The conclusion shows that, firstly, women's rights and position in Lampang Sebatin customary law community are far from fair principles. Not fair either in marriage law or inheritance law. Second, the form of injustice for women in indigenous communities of Lampung Sebatin, from gender analysis is marginalization, penomorduaan and labeling, violence, and excessive workload.
\end{abstract}

Keywords: Perempuan, Hukum dan Masyarakat Hukum Adat Lampung Sebatin 


\section{A. Pendahuluan}

Pembicaraan tentang tema-tema yang terkait perempuan dan hukum, baik hukum adat maupun hukum Islam merupakan wacana yang selalu menarik untuk diperbincangkan. Dalam rangka pengembangan dan memperkaya hasanah keilmuan, kajian seperti ini masih tetap eksis dan aktual. Analisis dari berbagai perspektif secara holistik dan progresif menyebabkan tema-tema tersebut senantiasa relevan dan kontekstual. Islam sebagai ajaran yang komperhensif dan universal, telah menempatkan perempuan pada posisi yang amat mulia, baik kedudukan maupun haknya. Di dalam Al-Qur'an berbicara tentang perempuan dalam berbagai surat, dan pembicaraan tersebut menyangkut berbagai sisi kehidupan. Pengakuan tentang kedudukan perempuan di dalam Al-Qura'an, terlebih kalau dilihat dari asal kejadian sebagai manusia; Surat Al-Hjurat ayat 13, AnNiss, Al-Isra' ayat $70^{1}$, sedangkan yang berkaitan dengan hakhak perempuan, dapat ditemukan di dalam Surat An-Nisa' ayat 32, 34, Al-Ahzab ayat 33, Ali-Imran ayat 95, Al-Baqoroh ayat 228 , At-Taubah ayat 71 , Al-Syura ayat $38 .^{2}$

Dalam realitas sosial, Islam tidak sekedar sejumlah doktrin yang bersifat menzaman dan menjagatraya (universal), tetapi mengejawantahkan diri dalam institusi-instutsi sosial yang dipengaruhi oleh situasi dan dinamika ruang dan waktu. ${ }^{3}$ Sebagai agama yang komprehensif, Islam menyatukan berbagai persoalan moril dan materil, serta mencakup berbagai kegiatan manusia dalam kehidupan dunia dan akhirat. ${ }^{4}$ Menurut Yusuf qardhawi ${ }^{5}$ Islam yang benar adalah 298-302.

${ }^{1}$ M. Quraish Shihab, Wawasan Al-Qur'an, Mizan, (Bandung, 1997), h.

IIbid., h. 303-318.

${ }^{3}$ Azyumardi Azra, Pergolakan Politik Islam Dari Fundamentalisme, Modernisme Hingga Post-Modernisme, (Paramadina: Jakarta, 1996), h.1.

${ }^{4}$ Yusuf Qardhawy, Min Fiqh ad Daulah fil-Islam Makanatuha, Ma'alimuha, Thbi'atahu, Manfiquha min ad-Dimaqratiyah wa at-Ta'addudiyah wal-Maar'ah wa Khairul Muslimin, (Kairo: Dar asy-Syuruq, 1997), Terjemahan Figh Negara, Ijtibad 
akidah dan ibadah, tanah air dan kebangsaan, toleransi dan kekuatan, moril dan meteril, kebudayaan dan hukum. Karena itu, aspek-aspek ajarannya yang bersifat universal tersebut tidak lepas dari kondisi sosial dimana ajaran itu dibumikan. Sebagai ajaran yang bersifat universal, penafsiran (interpretasi) terhadap ayat-ayat Al-Qur'an sering bahkan hampir menjadi perdebatan, terutama terkait dengan keseimbangan hak antara laki-laki dan perempuan. Secara normatif, Islam memang tidak membedakan hak perempuan dan laki-laki. Islam memberikan persamaan derajat antara laki-laki dan perempuan. Begitu juga dalam hal adat, budaya dan ideologi bukan satu hal yang turun dari langit. la di bentuk oleh manusia dan disosialisasikan dari satu generasi ke generasi berikutnya. Koentjaraningrat mengatakan nilai budaya adalah faktor mental yang menentukan perbuatan seseorang atau masyarakat ${ }^{6}$ Bagi masyarakat tradisional, budaya patriarki di pandang sebagai hal yang tidak perlu dipermasalahkan, karena hal tersebut selalu dikaitkan dengan kodrat dan kekuasaaan adikodrat yang tidak terbantahkan. Kepercayaan bahwa Tuhan telah menetapkan adanya perbedaan laki-laki dan perempuan, sebingga perbedaan dalam kehidupan manusia pun diatur berdasarkan perbedaan tersebut. Determinise biologis juga telah memperkuat pandangan tersebut. Artinya. karena secara biologis perempuan dan laki-laki berbeda maka fungsi-fungsi sosial ataupun kerja dengan masyarakat pun di ciptakan berbeda. Dalam kondisi yang seperti itu proses marjinalisasi terhadap perempuan terjadi pada gilirannya perempuan kehilangan otonomi atas dirinya. Eksploitasi serta kekerasan terjadi terhadap perempuan, baik di wilayah

Baru Seputar Sistem DemokrasiMulti Partai Keterlibatan Wanita Di Dewan Perwakilan Partisipasi Dalam Pemerintahan Sekuler, Robbani Press, Jakarta, 1997, h. 23.

${ }^{5}$ Ibid.

${ }^{6}$ Koentjaraningrat, Pengantar ilmu Antropologi, Jakarta: Aksara Baru, 1994), h. 188. 
domestik maupun publik. Dalam situasi demikian, maka perbedaan, diskriminasi, dan ketidakadilan gender tumbuh dengan suburnya. faktor-faktor sosio-histroris dan sosiokultural ummat Islam akan berpengaruh pada analisis dan pemahaman terhadap ajaran universal tersebut. Munculnya perbedaan pandangan dalam menganalisis persoalan disebabkan oleh banyak interpretasi (polyinterpretable), termasuk pembicaraan tentang perempuan dalam mendapat keadilan dari berbagai sisi. Dalam kehidupan sosial, politik, ekonomi, dan terlebih lagi dalam budaya, keadaan ketimpangan, asimetris dan subordinatif terhadap perempuan tampak sangat jelas. Dalam ranah hukum internasional, Indonesia telah meratifikasi Konvensi Mengenai Penghapusan Segala Bentuk Diskriminasi Terhadap Wanita (Konvensi Wanita) atau (CEDAW) dalam UU No. 7 Tahun 1984 tentang Konvensi Mengenai Penghapusan Segala Bentuk Diskriminasi Terhadap Wanita. UU ini berisi antara lain tentang menghapuskan diskriminasi dalam segala bentuknya terhadap wanita dan mungkin dalam terwujudnya prinsip-prinsip persamaan hak bagi wanita di bidang politik, hukum, ekonomi, dan sosial budaya. Namun apalah arti sebuah peraturan yang hanya tertulis diatas kertas tanpa implementasi nyata. Kondisi ini bertolak belakang dari gagasan hukum progrsif berasal dari Satjipto Rahardjo ${ }^{7}$, hukum adalah untuk manusia, bukan sebaliknya. Asumsi yang mendasari progresivisme hukum terdiri dari tiga hal. Pertama, hukum ada untuk manusia dan bukan untuk dirinya. Kedua, hukum selalu berada pada status law in the making dan tidak bersifat final. Terakhir, hukum adalah institusi yang bermoral kemanusiaan dan bukan tehnologi yang tidak berhati nurani. ${ }^{8}$

${ }^{7}$ Gagasan tentang hukum progresif pertama kali muncul tahun 2002 . Gagasan itu muncul melalui artikel yang ditlis Prof. Satjipto Rahardjo pada harian Kompas dengan judul Indonesia membutuhkan Penegakan Hukum Progresif, tanggal 15 Juni 2002.

${ }^{8}$ Ibid. 
Memperhatikan hal-hal yang mendasari progresivisme diatas, pada prinsipnya, keberadaan hukum sesungguhnya untuk melindungi manusia sebagai pengguna (user) atas hukum. Kendatipun secara jelas telah digariskan prinsip dasar tentang perempuan dan hak-haknya baik dalam hukum Islam, prinsip hukum internasional maupun dalam berbagai peraturan perundang-undangan, tetapi realitas menunjukkan masih banyak ketidakadilan di tengah masyarakat, tak terkecualikan perempuan dalam masyarakat hukum adat Lampung Sebatin. Baik dalam hukum perkawinan, hukum kewarisan serta pembatasan hak untuk menjadi pemimpin. Artikel ini akan menjawab permasalahan hak dan kedudukan perempuan pada masyarakat hukum adat Lampung Sebatin dan bentuk ketidakadilan bagi perempuan dalam masyarakat hukum adat lampung Sebatin.

Jenis penelitian ini adalah penelitian hukum empiris 9 (yuridis sosiologis) atau lebih dikenal sociological Jurisprudence ${ }^{10}$. Penelitian ini berbasis pada ilmu hukum normatif, tetapi bukan mengkaji mengenai sistem norma dalam aturan perundang-undangan, namun mengamati bagaimana reaksi dan interaksi yang terjadi ketika sistem norma itu bekerja di dalam masyarakat. Untuk menganalisis permasalahan dalam penelitian ini digunakan beberapa teori terkait, yakni teori hukum progresif, teori analisis gender, dan teori keadilan. Sedangkan analisisnya kualitatif bersifat deskriptif analitis, yaitu memaparkan dan menguraikan berbagai permasalahan yang berkenaan dengan Perempuan dan Hukum dalam Masyarakat Hukum Adat Lampung Sebatin

Pendekatan dalam penelitian ini adalah sosio legal (socio-legal research). Melalui pendekatan ini, obyek hukum diposisikan dalam konteks kemasyarakatan yang luas, dengan

${ }^{9}$ Mukti Fajar dan Yulianto Achmad, Dualisme Penelitian Hukum Normatif ¿ Empiris, (Yogyakarta: Pustaka Pelajar, 2010), h. 46.

${ }^{10}$ Ibid., h. 47. 
tidak menempatkannya sebagai bahan terberi yang terisolasi dari kebudayaan (sistem berfikir, sistem pengetahuan) dan relasi kekuasaan di antara para perumus hukum, penegak hukum, para pihak dan masyarakat luas. ${ }^{11}$ Penggunaan pendekatan ini dimaksud untuk menghindari ketimpangan dalam mengkaji hukum, karena di satu sisi hukum tidak dapat dilepas dari cirinya yang normatif, tetapi dalam hal pendekatan penelitian ini tidak selamanya murni yuridis juga pendekatan sosiologis, historis serta filosofis.

\section{B. Pembahasan}

\section{Hak dan Kedudukan Perempuan Pada Masyarakat Hukum Adat Lampung Sebatin}

Berbicara hak dan kedudukan perempuan di Indonesia pada umumnya, termasuk hak dan kedudukan perempuan dalam hukum pada masyarakat hukum adat Lampung Sebatin secara substantive maupun normative tidak perlu diragukan lagi. Baik yang diatur dalam hukum Islam maupun di dalam hukum positif. Sebagai ajaran yang bersifat universal, ketentuan-ketentuan yang terdapat di dalam hukum Islam itu tentunya berlaku juga bagi kaum perempuan yang berada di wilayah nusantara ini. Namun, ketika ajaran itu dikontekskan dengan suatu negara ataupun daerah tertentu, maka ajaran universalitas tersebut berbenturan dengan kondisi dan budaya yang bersangkutan. Di wilayah nusantara ini, masih banyak ditemukan berbagai masyarakat hukum adat yang masih eksis, termasuk diantaranya adalah masyarakat hukum adat Lampung.

Masyarakat hukum adat lampung secara garis besar dikelompokkan menjadi dua bagian yakni yang beradat pepadun dan sebatin. Masyarakat hukum adat Lampung Sebatin

${ }^{11}$ Sulistyowati Irianto, Memperkenalkan Studi Sosiolegal dan Implikasi Metodelogisnya, dalam Metode Penelitian Hukum, Konstelasi dan Refleksi, Editor Sulistyowati Irianto dan Shidarta, Yayasan Obor Indonesia, Jakarta, 2009, h. 177. 
mayoritas berdomisili di wilayah pesisir Lampung. Oleh sebab itu, disebut juga sebagai marga pesisir atau Lampung pesisir. Agama yang dianut oleh masyarakat adat lampung Sebatin adalah Islam dan dinominasi oleh budaya patriarki. Tetapi kenapa ajaran agama yang begitu melindungi hak dan kedudukan perempuan justru dikalahkan oleh budaya, terutama budaya yang lebih mengunggulkan laki-laki ketimbang perempuan. Sebagai dampak dari budaya patriarki, perempuan ditempatkan dalam posisi yang tidak adil. Menurut Yusuf qardhawi ${ }^{12}$ Islam yang benar adalah akidah dan ibadah, tanah air dan kebangsaan, toleransi dan kekuatan, moril dan meteril, kebudayaan dan hukum. Karena itu, aspekaspek ajarannya yang bersifat universal tersebut tidak lepas dari kondisi sosial dimana ajaran itu dibumikan. Sebagai ajaran yang bersifat universal, penafsiran (interpretasi) terhadap ayat-ayat Al-Qur'an sering bahkan hampir menjadi perdebatan, terutama terkait dengan keseimbangan hak antara laki-laki dan perempuan. Karena ayat-ayat Al-Qur'an yang terkait dengan hak dan kedudukan perempuan lebih banyak diintreprestasikan versi laki-laki sehingga penafsiran terhadap ayat-ayat tersebut cenderung melahirkan tafsir yang justru merugikan fihak perempuan. Kondisi ketidakadilan tersebut dapat dipetakan melalui analisis gender. Gender sebagai alat analisis, umumnya dipakai oleh penganut aliran ilmu sosial konflik yang justru memusatkan perhatian pada ketidakadilan struktural dan sistem yang disebabkan oleh gender. ${ }^{13}$ Analsis gender adalah struktur "ketidakadilan" yang ditimbulkan oleh peran gender dan perbedaan gender. ${ }^{14}$ Manifestasi dari ketidakadilan gender itu adalah: Pertama, Marginalisasi, pemiskinan ekonomi terhadap kaum perempuan. Kedua, Subordinasi, Dalam rumah tangga, masyarakat maupun

\footnotetext{
${ }^{12}$ Yusuf Qardhawy, Op. Cit., h. 23

${ }^{13}$ Mansour Fakih, Op.Cit., h. 71.

${ }^{14} I$ Ibid., h. 72.
} 
negara banyak kebijakan dibua tanpa 'menganggap penting' perempuan. Ketiga, Stereotipe atau pelabean negatif terhadap jenis kelamin tertentu. Keempat, kekerasan (violence) terhadap jenis kelamin tertentu. Kelima, Burden, memberikan beban kerja yang lebih banyak dan lama terhadap perempuan. Sejarah perbedaan gender (gender differences) antaramanusia jenis laki-laki dan perempuan terjadi melaui proses yang sangat panjang. Oleh karena itu, terbentuknya perbedaan gender dikarenakan oleh banyak hal, di antaranya dibentuk, disosialisaikan, diperkuat, bahkan dikonstruksi secara social atau cultural, melalui ajaran keagamamaan maupun Negara. ${ }^{15}$ Melalui proses panjang, sosialisai gender tersebut dianggap menjadi ketentuan Tuhan-seolah-olah bersifat biologis yang tidak bisa diubah lagi, sehingga perbedaan-perbedaan gender dianggap dan dipahami sebagai kodrat laki-laki dan kodrat perempuan.

Selain analisis gender, analisis feminisme juga dipakai dalam menganalsis hak dan kedudukan perempuan dalam masyarakat hukum adat Lampung Sebatin. Feminisme digunakan untuk menunjuk suatu teori kesetaraan jenis kelamin (sexual equality). Secara historis, istilah ini muncul pertama kali pada tahun 1895, sejak itu feminisme dikenal secara luas. ${ }^{16}$ Feminisme sebenarnya merupakan konsep yang muncul dalam kaitannya dengan perubahan social (social change), teori-teori pembangunan, kesadaran politik, perempuan dan gerakan pembebasan kaum perempuan, termasuk pemikiran kembali institusi keluarga dalam konteks masyarakat modern dewasa ini. Gerakan femisme, secara umum merupakan suatu reaksi atas ketimpangan dan ketidakadilan yang dihasilkan oleh suatu tatanan social yang

${ }^{15}$ Ibid.

${ }^{16}$ Lisa Tuttle, Encyclopedia of Feminsme, (New York: Facts of File Publication, 1986), h. 107. 
patriarkis. ${ }^{17}$ Dalam konteks Indonesia, kajian feminisme mulai marak kira-kira tahun 1980-an. Hal ini terlihat dari munculnya para aktifis gerakan perempuan, seperti Herawati, wardah Hafidz, Marwah Daud Ibrahim, Yulia Surya Kusuma, Ratna Megawangi dan lain sebagainya. Gerakan feminsme ini muncul salah satunya adalah karena adanya kesadaran bahwa dalam sejarah peradaban manusia termasuk di Indonesia, perempuan telah diperlakukan secara kurang adil bahkan dilecehkan. Namun ironisnya, hal ini dilakukan secara sistematis dengan adanya dominasi badaya yang patriarkis yang begitu kuat dalam sejarah manusia. Oleh karenanya, kritik yang tajam biasanya diarahkan pada persoalan sistem patriarki, genderisme dan seksisme. ${ }^{18}$

Dalam realitanya, sistem masyarakat yang patriarki dan hampir masuk pada seluruh segmen kehidupan cenderung memperlakukan perempuan secara tidak adil serta, dan memposisikannya secara subordinat di bawah laki-laki. Bahkan terkadang untuk memperkuat sistem patriarki tersebut, agama diikutsertakan dalam memberikan legitimasi, dengan cara menafsirkan kitab suci, hadist atau teks-teks keagamaan lainnya yang cenderung menguntungkan bagi pihak laki-laki. Legitimasi "religious-teologis" ini memang diperlukan meski terkadang disalahgunakan untuk kepentingan tertentu. Menurut mansour fakih, respon masyarakat Islam terhadap gerakan feminsme dapat dikatagorikan menjadi dua, yaitu: ${ }^{19}$

Pertama, Golongan anti feminsme. Golongan ini menganggap bahwa sistem relasi laki-laki dan perempuan di masyarakat telah sesuai dengan norma ajaran Islam. Oleh

${ }^{17}$ Abdul Mustaqim, Tafsir Feminis versus Tafsir Patriarki, Telaab Kritis Penafsiran Dekonstruktif Riffat Hasan, Sabda Persada, Yogyakarta, 2003, h. 19.

${ }^{18}$ Ibid.

${ }^{19}$ Mansour fakih, "Posisi Kaum Perempuan dalam Tradisi Islam: Tinjauan Analisis Gender" dalam Membincang feminisme, (Surabaya: Risalah Gusti, 1996), h. 40. 
karenanya, tidak perlu ada gerakan feminsme lagi. Golongan ini rupanya menghendaki adanya "status quo" dan menolak untuk mempermasalahkan kondisi maupun posisi kaum perempuan. Kedua, golongan pro feminisme. Golongan ini menganggap bahwa perempuan secara umum saat ini berada dalam suatu sistem patriarki yang diskriminatif serta diperlakukan secara tidak adil atau minimal kurang memperoleh apresiasi. Artinya, selama ini posisi dan kondisi perempuan secara factual-empiris belum menverminkan citaciat normatif ajaran Islam sebagaimana dalam al-Qur'an yang sangat menekankan prinsip keadilan.

Kaum perempuan dianggap telah menjadi korban ketidakadilan dalam berbagai bentuk dan aspek kehidupan yang didikonstruksikan secara social dan cultural (socially and culturally construction) oleh sistem masyarakat yang patriarki. Harus disadari bahwa tafsiran kitab suci al-Qur'an pun tidak lepas`dari sikap semacam itu, meskipun sebagian telah menggariskan norma-norma baru yang mengatasi kecenderungan tersebut. Namun, sikap social yang merendahkan perempuan tersebut agaknya sudah begitu meluas dan kuat, sehingga norma-norma kitab suci yang bersifat progresif menjadi terpengaruh serta ditafsirkan sesuai dengan sikap mental yang berlaku.

Dengan demikian, kondisi dan posisi perempuan yang diperlakukan secara tidak adil dan bahkan tertindas baik secara fisik maupun psikologis semakin memperoleh legitimasi dari penafsiran kitab suci al-Qur'an dan Hadist secara sepihak oleh kaum laki-laki. Padahal, sesungguhnya alQur'an itu lebih bersifat liberal dan menghargai dalam memperlakukan perempuan, dibandingkan dengan kitab suci lainnya. Dalam kenyataan historis sosiologis, ia juga mengalami nasib yang sama, yakni cenderung ditafsirkan sesuai dengan sikap mental masyarakat yang patriarki. Kuatnya pengaruh ideology patriarki dalam masyarakat hukum adat lampung Sebatin telah menempatkan para perempuan dalam posisi yang tidak adil. Dalam hukum 
perkawinan, masyarakat hukum adat lampung Sebatin menggunakan sistem perkawinan jujur. Artinya sistem perkawinan yang diawali dengan pembayaran uang jujur kepada pihak keluarga perempuan. Sebagai konsekuensi dari perkawinan tersebut, isteri dan anak-anak masuk dalam kerabat suami. Dalam hukum waris, masyarakat hukum adat Lampung menggunakan sistem kewarisan mayorat laki-laki. Sistem kewarisan mayorat laki-laki adalah sistem pewarisan hanya diberikan kepada anak laki-laki tertua. Terutama untuk harta pusaka, gelar adat dan termasuk harta pencaharian orang tua. Sedangkan untuk anak perempuan tidak mendapatkan hak waris. Posisi anak perempuan dalam hukum adat yang tidak mendapatkan hak waris adalah sangat bertentangan dengan prinsip kewarisan Islam, karena di dalam hukum kewarisan Islam seluruh anak berhak untu mendapatkan warisan orangtuanya. Dalam surat An-Nisa ayat 11 yang berbunyi sebagai berikut:

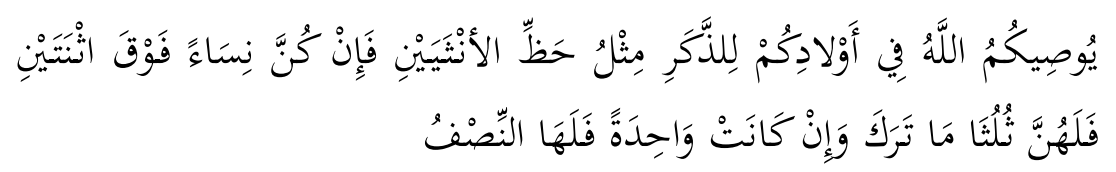

Artinya:

"Allah mensyari'atkan bagimu tentang pembagian pusaka untuk anak-anakmu. Yaitu: bahagian seorang anak lelaki sama dengan bahagian dua orang anak perempuan; dan jika anak itu semuanya perempuan lebih dari dua, maka bagi mereka dua pertiga dari harta yang ditinggalkan; jika anak perempuan itu seorang saja, maka ia memperoleh separo harta.." (Q.S. An-Nisa: 11).

Di dalam Pasal 176 Kompilasi Hukum Islam (KHI) menyatakan sebagai berikut : anak perempuan bila hanya seorang ia mendapat separuh bagian, bila dua orang atau lebih mereka bersama-sama mendapat dua pertiga bagian, dan apabila anak perempuan bersama-sama dengan anak laki-laki, maka bagian anak laki-laki adalah dua berbanding satu dengan anak perempuan." 
Dalam hukum waris Islam, pada prinsipnya pembagian terhadap anak laki-laki lebih besar dari anak perempuan. Walaupun pembagiannnya lebih kecil dibandingkan dengan anak laki-laki, Islam menghargai dan menghormati bahwa anak perempuan juga sebagai ahli waris.

Di dalam hukum adat dan masyarakat hukum adat Lampung Sebatin, anak perempuan tidak ditetapkan sebagai ahli waris. Harta waris hanya diberikan kepada anak laki-laki. Anak perempuan hanya mendapatkan pemberian ketika anak perempuan melaksanakan pernikahan, berbentuk perhiasan, sawah, ladang, tanah kavlingan dan peralatan rumah tangga. Berapa besar pemberian orang tua terhadap anak perempuan tergantung dari kondisi ekonomi orangtua.

Hukum dalam kehidupan manusia merupakan kebutuhan yang tidak dapat dihindari, terlebih jika hukum dianggap sebagai sarana untuk mendapatkan keadilan. Keadilan merupakan dambaan setiap ummat manusia termasuk kaum perempuan. Namun, ketika konsep keadilan dikontekskan atau dibumikan pada suatu kondisi sosial tertentu, keadilan tersebut justru semakin susah untuk diperoleh. Banyak faktor yang menyebabkan ketidakadilan itu muncul, diantaranya adalah pangaruh interpretasi ataupun konstruksi budaya. Salah satu ketidakadilan dalam masyarakat yang kita ketemukakan adalah ketidakadilan gender (gender inequalities).

Keadilan merupakan kebutuhan spritual setiap manusia. Persoalan-persoalan keadilan bersifat parenial, ada sepanjang kehidupan manusia. Muslihuddin dalam disertasinya berjudul "Philosophy of Islamic Law and The Orientalis" (1986), mengemukakan bahwa cita-cita keadilan telah diformulasikan oleh para pemikir hukum dalam berbagai cara, dan kita melihat banyak teori yang satu sama lain berbeda, masing-masing mengklaim kebenaran mutlak. Elaborasi terhadap teori-teori keadilan dari filsuf terdahulu, seperti : Plato, Aristoteles, Hans Kelsen, Hebert Spencer, W.R. Sorley,Thomas Aquinas, dan lain-lain, antara lain 
menghasilkan kesimpulan bahwa keadilan menuntut kebebasan, kesamaan dan hak-hak dasar lainnya yang diselaraskan, dan melindungi ummat manusia untuk mendapatkan sebanyak mungkin sesuai dengan kebaikan umum.

Keadilan dapat dibagi dua, yaitu keadilan individual dan keadilan sosial. Keadilan individual adalah keadilan yang tergantung dari kehendak baik atau buruk masing-masing individu. Sedangkan keadilan sosial adalah keadilan yang pelaksanaannya tergantung dari struktur-struktur kekuasaan dalam masyarakat, struktur-struktur mana terdapat dalam bidang politik, ekonomi, sosial, budaya dan ideologi. Menurut Darji Darmodiharjo keadilan sosial dalam Pancasila berarti setiap orang Indonesia mendapat perakuan yang adil dalam bidang hukum, politik, ekonomi dan kebudayaan. Oleh karena kehidupan manusia itu meliputi kehidupan jasmani dan kehidupan rohani, maka keadilan itu meliputi keadilan bidang material dan spiritual.

\section{Bentuk Ketidakadilan bagi Perempuan dalam Masyarakat Hukum Adat Lampung Sebatin}

Bagi masyarakat tradisional, budaya patriarki di pandang sebagai hal yang tidak perlu dipermasalahkan, karena hal tersebut selalu dikaitkan dengan kodrat dan kekuasaaan adikodrat yang tidak terbantahkan. Kepercayaan bahwa Tuhan telah menetapkan adanya perbedaan laki-laki dan perempuan, sebingga perbedaan dalam kehidupan manusia pun diatur berdasarkan perbedaan tersebut. Determinise biologis juga telah memperkuat pandangan tersebut. Artinya. karena secara biologis perempuan dan laki-laki berbeda maka fungsi-fungsi sosial ataupun kerja dengan masyarakat pun di ciptakan berbeda. Dalam kondisi yang seperti itu proses marjinalisasi terhadap perempuan terjadi pada gilirannya perempuan kehilangan otonomi atas dirinya. Eksploitasi serta kekerasan terjadi terhadap perempuan, baik di wilayah 
domestik maupun publik. Dalam situasi demikian, maka perbedaan, diskriminasi, dan ketidakadilan gender tumbuh dengan suburnya. faktor-faktor sosio-histroris dan sosiokultural ummat Islam akan berpengaruh pada analisis dan pemahaman terhadap ajaran universal tersebut. Munculnya perbedaan pandangan dalam menganalisis persoalan disebabkan oleh banyak interpretasi (polyinterpretable), termasuk pembicaraan tentang perempuan dalam mendapat keadilan dari berbagai sisi. Dalam kehidupan sosial, politik, ekonomi, dan terlebih lagi dalam budaya, keadaan ketimpangan, asimetris dan subordinatif terhadap perempuan tampak sangat jelas. Dalam budaya kita, seperti juga di banyak negara dunia ketiga lain, budaya patriarki masih sangat kental. Berbagai gugatan terhadap ketidakadilan tersebut, terdapat satu analisis yang mempertanyakan ketidakadilan sosial dari aspek perbedaan perilaku (behavioral differences) antara laki-laki dan perempuan yang dikonstruksi secara sosial, yakni analisis gender. Analisis gender dan teori gender merupakan alat analisis untuk memahami realitas sosial. Perbedaan gender sebenarnya tidak ada masalah sepanjang tidak melahirkan ketidakadilan gender. Namun, yang terjadi ketidakadlan gender ini melahirkan berbagai ketidakadilan bagi perempuan, khususnya bagi perempuan yang berada pada masyarakat hukum adat Lampung Sebatin. Mereka beranggapan bahwa kondisi itu merupakan budaya yang harus dilestarikan dan tidak ada upaya untuk melakukan perlawanan.

Jadi, kendatipun telah secara jelas digariskan prinsip dasar tentang perempuan dan hak-haknya baik dalam hukum Islam, prinsip hukum internasional maupun dalam formulasi kebijakan, tetapi realitas menunjukkan bahwa seiring dengan pelaksanaan pembangunan, ternyata masih banyak ketimpangan dan ketidak adilan di tengah masyarakat, lebih khusus ketidak adilan gender yang terdapat pada masyarakat hukum adat Lampung Sebatin. 
Kuatnya pengaruh ideology patriarki dalam masyarakat hukum adat lampung Sebatin telah menempatkan para perempuan dalam posisi yang tidak adil. Jika hal tersebut dianalisis dalam perpeketif analisis gender, sangat terlihat beberapa ketidak adilan gender yang ada dalam masayarakat adat Lampung Sebatin. Gender sebagai alat analisis, umumnya dipakai oleh penganut aliran ilmu sosial konflik yang justru memusatkan perhatian pada ketidakadilan struktural dan sistem yang disebabkan oleh gender. Analsis gender adalah struktur "ketidakadilan" yang ditimbulkan oleh peran gender dan perbedaan gender. Manifestasi dari ketidakadilan gender itu adalah: Pertama, Marginalisasi, pemiskinan ekonomi terhadap kaum perempuan. Kedua, Subordinasi, Dalam rumah tangga, masyarakat maupun negara banyak kebijakan dibua tanpa 'menganggap penting' perempuan. Ketiga, Stereotipe atau pelabean negatif terhadap jenis kelamin tertentu. Keempat, kekerasan (violence) terhadap jenis kelamin tertentu. Kelima, Burden, memberikan beban kerja yang lebih banyak dan lama terhadap perempuan.

Bagi masyarakat adat Lampung Sebatin "ketidakadilan" yang ditimbulkan oleh peran gender dan perbedaan gender, dapat terlihat dalam kehidupan sehari-hari baik dalam lingkungan domistik keluarga maupun dalam sektor publik. Berdasarkan pengamatan di dalam penelitian bahwa perbedaan gender bagi masyarakat hokum adat lampung Sebatin, telah mengakibatkan lahirnya sifat stereotipe yang oleh masyarakat hokum adat Lampung Sebatin dianggap sebagai ketentuan kodrati atau bahkan ketentuan Tuhan. Sifat dan stereotipe yang sebetulnya merupakan konstruksi ataupun rekayasa social dan akhirnya dikukuhkan menjadi kodrat cultural, dalam proses yang panjang akhirnya telah mengakibatkan terkondisikannya beberapa posisi perempuan dalam masyarakat hukum adat lampung Sebatin. 
Dalam sector domistik, perbedaan gender dan pembagian gender menjadikan perempuan masyarakat hukum adat Lampung Sebatin bekerja lebih keras dengan memeras keringat lebih panjang (double-burden). Pada umumnya, jika dicermati, di suatu rumah tangga ada beberapa jenis pekerjaan pekerjaan yang harus dilakukan oleh laki-laki dan ada pekerjaan yang harus dilakukan oleh perempuan. Di dalam kenyataan hasil penelitian menunjukkan bahwa hampir 90\% pekerjaan domistik dilakukan oleh perempuan.

Dalam sector public, perbedaan gender dan pembagian gender menjadikan perempuan masyarakat hokum adat Lampung Sebatin, senantiasa berada pada posisi tersubrodinasi. Subordinasi sering terkait dengan proses pengabilan keputusan dan pengendalian kekuasaan. Memperjuangkan keadilan gender merupakan tugas berat, karena masalah gender adalah masalah yang sangat intens, di mana kita masing-masing terlibat secara emosional. Banyak terjadi perlawanan manakala perjuangan ketidakadilan gender diaktifkan, karena menggugat masalah gender sesungguhnya berarti menggugat privilege yang kita dapatkan dari adanya ketidakadilan gender. Persoalannya, spectrum ketidakadialn gender sangat luas, mulai yang berada di kepala dan di dalam keyakinan kita masing-masing, sampai urusan negara.

Ketidakadilan gender merupakan bentuk perbedaan perlakuan berdasarkan alasan gender, seperti pembatasan peran, penyingkiran atau pilih kasih yang mengkibatkan terjadinya pelanggaran atas pengakuan hak asasi, persamaan hak antara laki-laki dan perempuan, maupun hak dasar dalam bidang sosial, politik, ekonomi, budaya dan lain-lain. Bentukbentuk ketidakadilan bagi perempuan dalam masyarakat hukum adat lampung Sebatin, dilihat dari analisi gender adalah peminggiran (Marginalisasi), penomorduaan (Subordinasi), pelabelan (Stereotip), kekerasan (Violence), beban kerja berlebihan (Multiple Burden). Untuk melihat ketidakadilan gender perempuan dan hokum dalam masyarakat hokum adat Lampung Sebatin, dapat dilhat melalui tabel berikut: 


\begin{tabular}{|c|c|}
\hline Bentuk & Dalam Bidang Hukum \\
\hline Marginalisasi & $\begin{array}{l}\text { 1. Hukum Perkawinan; seorang isteri senantisasa } \\
\text { harus patuh dan ikut apa kata suami, maka dalam } \\
\text { hak kepemilikan harta benda harus atas nama } \\
\text { suami. Disini kaum perempuan, diposisikan sebagai } \\
\text { abdi atas tuannya, yaitu suami. Sebagai implikasi } \\
\text { dianutnya sistem perkawinan jujur. } \\
\text { 2. Hukum Kewarisan: anak perempuan pada } \\
\text { masyarakat hokum adat Lampung Sebatin tidak } \\
\text { mendapat warisan, karena sistem kewarisan yang } \\
\text { dipakai adalah mayorat laki-laki, sehingga harta } \\
\text { warisan jatuh pada anak laki-laki tertua. perempuan } \\
\text { cenderung dimarginalkan, yaitu diletakkan di } \\
\text { pinggir. }\end{array}$ \\
\hline Subordinasi & $\begin{array}{l}\text { Hukum Keluarga: Dalam memberikan prioritas } \\
\text { pendidikan untuk menyekolahkan anak, anak } \\
\text { perempuan selalu dinomorduakan,dengan alasan anak } \\
\text { perempuan tidak perlu sekolah tinggi-tinggi toh juga } \\
\text { nanti akan kedapur juga. } \\
\text { Perempuan harus tunduk kepada kaum lelaki. } \\
\text { Pemimpin atau imam hanya pantas dipegang oleh } \\
\text { lelaki; perempuan hanya boleh menjadi makmum saja. }\end{array}$ \\
\hline $\begin{array}{l}\text { Violence } \\
\text { atau } \\
\text { Kekerasan }\end{array}$ & $\begin{array}{l}\text { Hukum perkawianan; Keluarga dianggap sebagai } \\
\text { lembaga yang menyebabkan adanya pembagian } \\
\text { kekuasaan, sehingga ketika isteri melakukan kesalahan } \\
\text { kecil, tidak menutup kemungkinan akan menerima } \\
\text { perlakuan yang kemudian dikenal dengan istilah } \\
\text { KDRT (Kekerasan Dalam Rumah Tangga). Kekerasan } \\
\text { di dalam rumahtangga, bukan hanya sebatas kekerasan } \\
\text { fisik, melainkan juga kekerasan psikis. Kekerasan fisik } \\
\text { terhadap perempuan masyarakat adat lampung Sebatin, } \\
\text { banyak pihak suami yang memperlakukan isteri tidak } \\
\text { manusiawi. Isteri disuruh mencari nafkah di Negara } \\
\text { orang, sementara suami tidak bekerja dan hanya diam } \\
\text { saja dirumah, menunggu kiriman uang dari isterinya. }\end{array}$ \\
\hline
\end{tabular}




\begin{tabular}{|l|l|}
\hline Beban Kerja & Hukum Perkawinan; peran isteri lebih banyak jam \\
Berlebihan & kerja dibandingkan dengan suami. Mulai dari urusan \\
(Multiple & rumah tangga hingga urusan diluar rumah. Karena \\
Burden $)$ & masyarakat adat lampung Sebatin, mayoritas bekerja \\
& sebagai masyarakat petani, setelah mengerjakan urusan \\
& rumahtangga mereka bekerja di kebun pulang \\
& menjelang sore dengan membawa sayur dan kayu \\
& bakar dan sesampainya di rumah harus memasak dan \\
& menyiapkan makanan untuk keluarga. \\
\hline
\end{tabular}

\section{Kesimpulan}

1. Hak dan kedudukan perempuan dalam masyarakat hukum adat Lampung Sebatin, dapat dikatakan jauh dari prinsip adil. Bahkan belum memenuhi keadilan, baik hukum perkawinan maupun hukum kewarisan.

2. Bentuk ketidakadilan bagi perempuan dalam masyarakat hukum adat lampung Sebatin, dilihat dari analisi gender adalah peminggiran (Marginalisasi), penomorduaan (Subordinasi), pelabelan (Stereotip), kekerasan (Violence), beban kerja berlebihan (Multiple Burden).

\section{Daftar Pustaka}

Abdul Mustaqim, Tafsir Feminis Versus Tafsir Patriarki, Telaah Kritis Penafsiran Dekonsruktif Riffat Hassan, Sabda Persada, Yogyakarta, 2003,

Azyumardi Azra, Pergolakan Politik Islam Dari Fundamentalisme, Modernisme Hingga Post-Modernisme. Paramadina, Jakarta, 1996

Hadari Nawawi, Metode Penelitian Bidang Sosial, Ggajah Mada University Press, Yogyakarta, 2005 
Koentjaraningrat, Pengantar ilmu Antropologi, Aksara Baru, Jakarta, 1994

M. Quraish Shihab, Wawasan Al-Qur'an, Mizan, Bandung, 1997

Mansour Faqih, Analisis Gender dan Transformasi Sosial, Pustaka Pelajar, Yogyakarta, 1997

Mukti Fajar dan Yulianto Achmad, Dualisme Penelitian Hukum Normatif \& Empiris, Pustaka Pelajar, Yogyakarta, 2010

Satjipto Rahardjo, Membedah Hukum Progresif, Penerbit Buku Kompas, Jakarta, 2006

Siti Ruhaini Dzuhayatin dkk, Rekonstruksi Metodologis Wacana Kesetaraan Gender Dalam Islam, Pustaka Pelajar, Yogyakarta, 2002

Soerjono Soekanto, Hukum Adat Indonesia, Raja Grafindo Persada, Jakarta, 2011,

Sulistyowati Irianto (Editor), Memperkenalkan Studi Sosiolegal dan Implikasi Metodelogisnya, dalam Metode Penelitian Hukum, Konstelasi dan Refleksi, Sulistyowati Irianto dan Shidarta, Yayasan Obor Indonesia, Jakarta. Qurratul Ainiyah, Keadilan Gender Dalam Islam, Konvensi PBB Dalam Perspektif Mazhab Shafi'i, Kelompok Instrans Publishing, Malang, 2009

Yunahar Ilyas, Kesetaraan Gender Dalam Al-Qur'an Studi Pemikiran Para Mufassir, Itqan Publishing, Yogyakarta, 2015

Yusuf Qardhawy, Fiqh Negara, Ijtihad Baru Seputar Sistem Demokrasi Multi Partai Keterlibatan Wanita di Dewan Perwakilan Partisipasi Dalam Pemerintahan Sekuler, Robbani Press, Jakarta, 1997 